\title{
sciendo KNOWLEDGE MANAGEMENT AS A COMPONENT OF INTEGRATED MANAGEMENT SYSTEMS
}

doi:10.2478/mape-2018-0065

Date of submission of the article to the Editor: 05/2018

Date of acceptance of the article by the Editor: 07/2018
MAPE 2018, volume 1, issue 1, pp. 515-520

\author{
Eng. Zbigniew Skuza, PhD \\ Assoc. Prof. Rafał Prusak \\ Czestochowa University of Technology, Poland
}

\begin{abstract}
Integrated management systems are increasingly used in modern enterprises. They allow for a more comprehensive approach to a number of important issues, affecting the modification of activities and process improvement. However, the integration itself often does not provide the right effects (apart from economic ones) without leading to real, multifaceted coupling of activities between the components of the system. To obtain such effects, it is necessary to connect the components in one system. Knowledge management can be a helpful element in this activity. Each component of the integrated management systems generates a large number of data and information. Their use is possible only by building on their basis knowledge leading to improvement of activities or innovation. The use of knowledge, especially hidden knowledge that contains unique and inaccessible knowledge for competitors, should be a priority for today's enterprises.

The study presents considerations regarding the possibility of including knowledge management in integrated management systems, treating knowledge as a basic element connecting the system.
\end{abstract}

Keywords: integrated management systems, knowledge management,

\section{INTRODUCTION}

Integration processes in the European Union as well as the effects of globalization currently create market conditions that narrow to some extent the areas through which the company can gain a competitive advantage. At the same time, modern enterprises wanting to increase their market competitiveness must take into account many factors, both external and internal. The development of information and communication technologies, access to capital or new technology forces the search for their own competitive advantage, especially in the area of intangible assets difficult to copy (Tyrańska, 2009). The market success is increasingly determined by such elements as (Walczak, 2017) key competences, human capital, skills, abilities, technological potential and intellectual capital that the company has at its disposal. All these elements are closely related to the broadly understood knowledge accumulated in the company. Proper knowledge management leading to the identification of its sources, targeted development and effective use is becoming a priority for many modern enterprises. In general, knowledge contributes to the improvement of the enterprise in two areas: to the proper functioning of the organization currently, and, being a key strategic factor, enabling the development of the enterprise. One of the elements connecting these two areas is quality management. It seems that such sentences as: quality is a necessary condition but not enough to achieve market success (Skuza et al., 2011) or success refers to the company to which customers return not goods (Skrzypek, 2005) - belong to pass because every contemporary organization is aware of this. Already in the last century, according to statistics, faulty equipment meant that nine out of ten users did not return to the products of a given brand. At the same time customer, satisfied with the purchase, recommended the product to two others, while the unsatisfied one warned from eight to sixteen people (Łańcucki et al., 1995). Taking additionally into account the fact that getting a new client costs five times more than 
maintaining the current one (Łańcucki et al., 1995), it can be assumed that quality has already become a permanent element of the production management system.

Quality management in an enterprise should not be limited to the current assurance of product reliability. The desire to constantly improve, striving for perfection stimulates innovations both in the sphere of the product and in the area of manufacturing processes. The proposed already in ISO 90002000 recommendation to satisfy current and future customer needs highlights the role that can meet the quality of the company's development.

Currently, the content of the term quality of products includes not only the technical aspect, but also the market aspect. The center of gravity of ensuring product properties and features has shifted to ensuring working conditions and the quality of connections with the environment and social responsibility (Lisiecka, 2002). It is suggested that quality as a discipline will become even more "ubiquitous" (Ligarski, 2000). This approach is not something completely new because Gemichi Taguchi already believed that the quality of the product is a loss transferred by the product to society, counting from the time of sending this product. Therefore, he assumed that each product transferred to the user causes a loss the smaller the higher its quality. Commonly, these losses are understood as pollution of the natural environment, related civilization diseases, health and safety at work, but also consumer dissatisfaction or producer's loss caused by an unfavorable image of the organization, causing a loss of sales markets in the long run (Łańcucki et al., 1995).

Currently, many enterprises have an integrated management system, which usually includes: a quality management system (compliant with ISO 9000 requirements), an environmental management system (compliant with ISO 14000 standards) and a health and safety management system (compliant with PN-N-18000 standards) or the ISO 45001 standard published on March 12). Of course, depending on the type of business activity conducted by a given organization, other aspects may be subject to, such as: information security management system (compliant with ISO 27000 standards) or energy management system (compliant with ISO 5000 standards). These standards are usually combined with the organizational benefits in mind, often ignoring the logical connections between the systems. Removing, for example, non - compliances discovered during production may result in additional energy consumption or unnecessary exposure to the employee's health and safety. It should be noted, however, that in many cases the elements of integrated management systems (health and safety, environmental protection, quality management), despite the interrelations between them and assigning them an equal role are considered in the tactical and operational context and to a much lesser extent in the strategic dimension. The use of a full, comprehensive analytical perspective requires the analysis of the huge amount of data generated by individual components of the system and the search for relationships and dependencies between them. The task is difficult because dependencies are not always easily perceptible, easy to interpret and understand, therefore companies very often remain with large amounts of data and information, which, however, are not transformed into the knowledge necessary to undertake modifiable activities or innovative. Knowledge management, which is a key intangible asset of an enterprise that allows building unique market advantages, can become an overriding element allowing for subordination of all components of integrated management systems to one overriding goal. As a result, it will be possible to increase the efficiency of using the data and information generated by the system and, among others, lead to its continuous improvement.

\section{KNOWLEDGE MANAGEMENT}

People are the key to quality (Dahlgaard et al., 2000). Man as the only resource of the enterprise is subjective in nature, i.e. it is capable of independent, creative decision-making. Concepts such as knowledge, competences or skills make human resources a direct or indirect source and measure of the organization's success in every aspect of its activity. 
Elements of knowledge management have already been included in the ISO 9001 system from 2000, among others in recommendations (Ejdys, 2007):

- the organization should ensure availability of resources and information necessary to support and monitor defined processes,

- personnel performing work affecting the quality of the product should be competent on the basis of appropriate education, training, skills and experience (individual knowledge),

- data analysis should provide information on: customer satisfaction, compliance with product requirements, characteristics and trends of processes and products and suppliers.

The revision of the ISO 9001 standard from 2015 meant that more attention was paid to knowledge management issues. This issue was devoted to the whole subsection (7.1.6 Knowledge of the organization) in which the following issues were included (ISO, 2015):

- the organization should define the knowledge necessary for the functioning of its processes and to achieve compliance of products and services,

- this knowledge should be maintained and made available to the extent necessary,

- when considering changing needs and trends, the organization should consider its current state of knowledge and determine how to acquire or access any necessary additional knowledge and the required update.

The discussed norm also defines the knowledge of the organization as knowledge appropriate for a given organization, gained through experience (information that is used and made available to achieve the organization's goals). It was also emphasized that this knowledge may be based on sources (ISO 2015):

- internal (eg intellectual property, knowledge gained from experience, knowledge brought about from mistakes and successful projects, acquisition and sharing of undocumented knowledge and experience, results of improvement of processes, products and services),

- external (eg standards, academic environments, conferences, knowledge gained from clients and external suppliers).

Current market conditions narrow to some extent the areas through which the company can gain a competitive advantage. Organizations operating in a similar environment may therefore be forced to compete with each other mainly in the sphere of efficient and effective management. The management process of every aspect, including quality, is directly related to, among others with knowledge (Figure 1). Everything an enterprise knows and can effectively and effectively use is one of the key elements of market success.

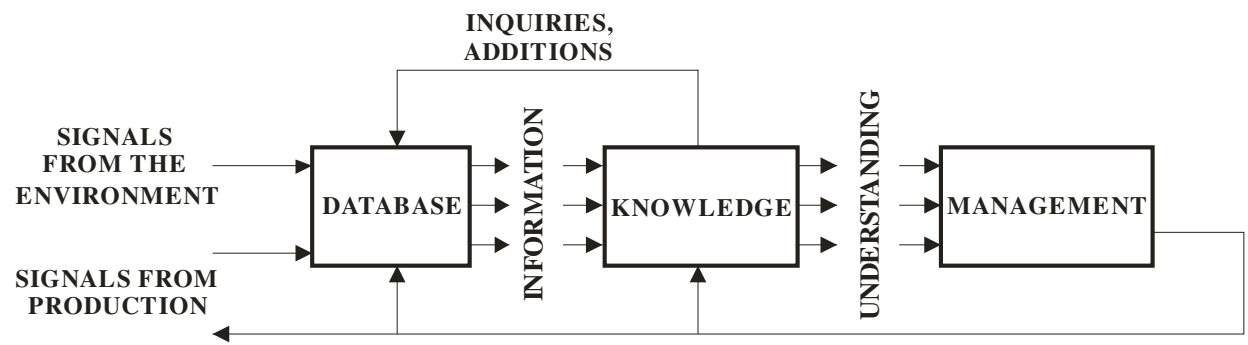

Fig. 1. Relation of knowledge with the management process

Knowledge - according to popular opinion - becomes a priority factor of production and an important determinant of technical progress (Soto-Acosta, et al., 2017). This theory is proved by the successes of a knowledge-based economy, according to which (Gabryś, 2001):

- knowledge is the most valuable resource,

- the highest competitive potential is possessed by products whose main ingredient is knowledge,

- human capital is subject to the largest changes among all production factors,

- the greatest added value is created by companies investing in human capital and able to effectively use external sources of knowledge. 
Nonaka and Takuchi (2000) divide organizational knowledge into three basic categories:

- a personalized core of knowledge (explicit and hidden knowledge),

- codified knowledge (documentation, reports, publications, databases, projects),

- well-established applied knowledge (processes, services, products, relationships, technologies).

Public knowledge is usually available to everyone, is stored in databases, library or online resources. Everyone can use it. Of course, the way knowledge is used plays an important role and the key position in it is played by the managerial staff (Kiełtyka et al., 2010). In today's reality, however, it is very easy to copy proven solutions, especially when a competitor knows what was the basis for their creation. The use of hidden knowledge (Nonaka, 1994), by definition inaccessible to all, hinders such activities and allows to extend in time the possibility of using the built-up market advantage (Boiral, 2002). For this reason, the identification and use of hidden knowledge should be one of the priorities of modern enterprises (Monteiro, Birkinshaw, 2017).

\section{INTEGRATED MANAGEMENT SYSTEMS}

Knowledge management is not the only area (indirectly defined with quality) that has been highlighted in ISO 9001 from 2015. Such records as (ISO, 2015):

- the organization should identify, ensure and maintain the environment (social, psychological, physical) necessary for the functioning of processes and the compliance of products and services;

- the documented information required by the quality management system should be supervised to ensure: their availability and suitability for use; their proper protection;

- post-delivery activities may include actions taken in relation to the guarantee, contractual obligations such as service, and additional services such as recycling or final disposal;

suggest that aspects such as occupational health and safety, information security or environmental protection can be part of quality management.

Quality management therefore requires identification of all elements of the life cycle of the product. The quality circle shown in Figure 2 distinguishes three basic phases of such a cycle:

- pre-production phase,

- production phase,

- post-production phase.

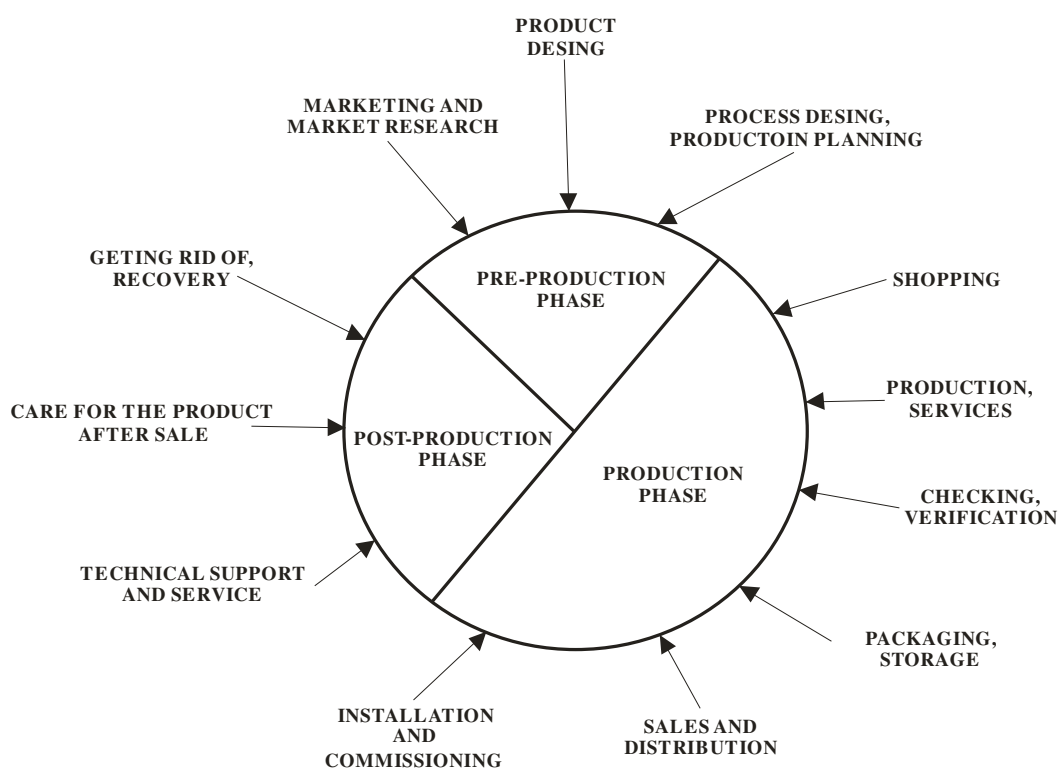

Fig. 2. Quality Circle

Source: (Hamrol and Mantura, 2002). 
The quality understood in this way is far from its subjective meaning, because the center of gravity from the assurance of the product's properties and features has shifted to ensuring working conditions (work culture) and the quality of connections with the environment and social responsibility. This situation requires from a modern enterprise that the control and regulation of the process of product quality creation should replace the management of this value. This change would make it possible to control the quality, and thus to prevent errors in all areas of the enterprise's operation (also in its environment) (Lisiecka, 2002).

Quality development within the company should therefore include improvement of all processes, both in terms of product quality and "quality of production". Although these two elements are permanently interlinked, however, such aspects of "production quality" as occupational health and safety and environmental protection should be just as important as ensuring the assumed set of inherent properties of the product. These aspects, which are the basis of an integrated management system, must also be perceived by potential co-operators providing us with specific elements of the entry vector.

Management systems used in organizations can be implemented using an unnormalized or standardized approach. The non-standard approach based on its own internal guidelines and assumptions is not subject to external evaluation. On the contrary, the more commonly used standard approach is to use systems that meet the requirements set out in the standards and is provided on the external evaluation of independent accreditation bodies. In this case, there is often a conviction that a standardized system guarantees operational effectiveness, with minimal involvement of the organization's resources (Ejdys, 2011).

A more advanced approach to the integration process, with regard to the integration of formal requirements of individual systems, is an approach based on a culture of continuous learning, involving all interested parties in the integration process, continuous improvement of all areas of activity towards sustainable development. The idea of such full integration is reflected, for example, in TQM (Total Quality Management) or ITQ (Integrated Total Quality), which one of the basic principles presupposes a change of the economic balance approach towards economic balance (quality management system), environmental (environmental management system) and social (OSH management system) (Ejdys, 2011).

\section{CONCLUSION}

The process of improving quality management should cover the whole life cycle of the product. This approach, in line with the idea of sustainable development promoted by the European Union, requires the quality view proposed by Taguchi.

In many cases, the final product is created with the cooperation of many sub-suppliers and its quality is in a sense the sum of the quality of individual components. A given product may be, for example, ecological in use, but during its production, installations that were harmful to the environment were used or made by co-operators. Especially in the era of globalization, as in relational marketing (Adamczak, 2018), shaping quality requires mutual long-term contacts with contractors.

Quality taking into account occupational health and safety and environmental protection can not only apply to certain elements of the product. It should be evaluated throughout the entire life cycle. However, this assessment must take into account the specificity of the industry concerned. Entrepreneurs noticing interrelations point out that they are often perceived by a specific production process, although they often indirectly support the achievement of goals related to sustainable development (Myszor and Samaddar, 2018).

At the organizational unit level, the concept of sustainable development is usually implemented based on management systems related to the previously mentioned areas, ie quality, environment and health and safety. These aspects that form an integrated management system often treated as tools of competitiveness are focused only on improvement processes in the sphere of operational activities. Enterprises equipped with computer management systems have practically many-year data sets from production, but without proper 
interpretation of them, these databases become useless. Only comprehensive and methodical transformation will allow the organization to have useful knowledge that employees can use. The problem of the proper use of knowledge of a given organization has been noticed in numerous publications. In one of them, the author proposes that the concept of a knowledgebased organization (knowledge-based action strategy) be used to improve standardized management systems. These systems, as noted, mainly give concerts on explicit knowledge, and to a limited extent relate to hidden knowledge, which seems to be a key determinant of the organization's innovativeness, including management systems (Ejdys, 2011).

\section{REFERENCES}

Adamczak, M. (2018). Marketing partnerski. [online] Available at: www. medina-psicologia.ugr.es [Accessed 2 Feb. 2018).

Boiral, O. (2002). Tacit Management and Environmental Management. Long Range Planning, 35, p. 296. Dahlgaard, J.J., Kristtensen, K., Kanji, G. K. (2000). Podstawy zarządzania jakością, Warszawa: PWN.

Ejdys, J. (2007). Zarządzanie wiedzą - czynnikiem doskonalenia systemów zarządzania. Problemy jakości, $5 / 2007$.

Ejdys, J. (2011). Model doskonalenia znormalizowanych systemów zarządzania oparty na wiedzy, Białystok: Biblioteka o zarządzaniu.

EN ISO 9001:2015

Gabryś, K. (2001). Wiedza i szkolnictwo wyższe obszarem wyzwań współczesnego procesu internacjonalizacji. In: Bylok F., Słocińska, A., ed., Współczesne oblicza kapitału ludzkiego i intelektualnego. Częstochowa: Wydawnictwo Politechniki Częstochowskiej, p. 73.

Hamrol, A., Mantura, W. (2002). Zarządzanie jakością. Teoria i praktyka, Warszawa: PWN.

Kiełtyka, L., Sokołowski, A., Wrzalik, A. (2010). Modelowanie procesów decyzyjnych menedżera wiedzy. In: Kiełtyka, L., ed., Analiza i modelowanie procesów decyzyjnych menedżera z wykorzystaniem systemów rozmytych. Toruń: Wydawnictwo „Dom Organizatora", p. 109.

Ligarski, M. J. (2010). Podejście systemowe do zarządzania jakością w organizacji. Gliwice: Wydawnictwo Politechniki Śląskiej.

Lisiecka, K. (2002). Kreowanie jakości. Katowice: Akademia Ekonomiczna Im. Karola Adamieckiego.

Łańcucki, J., Kowalska, D., Łuczak, J.(1995). Zarządzanie jakością w przedsiębiorstwie. Bydgoszcz: Biblioteka Menadżera i Służby Pracowniczej.

Monteiro, F., Birkinshaw, J. (2017). The external knowledge sourcing process in multinational corporations. Strategic Management Journal, 38 (2)/2017.

Myszor, P. Samaddar (2018). AMP: Na CO2 z procesu metalurgicznego należy spojrzeć inaczej niż dotąd. [online] Available at: www.wnp.pl [Accessed 20 Feb. 2018].

Nonaka, I. (1994). A dynamic theory of organizational knowledge creation. Organization Science, $5(1) / 1994$.

Nonaka, I., Takeuchi, H. (2000). Kreowanie wiedzy w organizacji. Warszawa: Poltext.

Skrzypek, E. (2005). Wpływ zarządzania jakością na konkurencyjność przedsiębiorstwa w UE. Problemy jakości, 11/2005.

Skuza, Z., Prusak, R., Budzik, R. (2011). Contemporary elements of system of quality management in metallurgical enterprises. Metallurgy, vol. 50 (2), p. 137.

Soto-Acosta, P., Popa, S., Palacios-Marques, D. (2017). Social web knowledge sharing and innovation performance in knowledge-intensive manufacturing SMEs. Journal of Technology Transfer, $42(2) / 2017$.

Tyrańska, M. (2009). Jakość kapitału ludzkiego a efektywność przedsiębiorstwa. Problemy jakości, $5 / 2009$ r.

Walczak, W. (2017). Analiza czynników wpływających na konkurencyjność przedsiębiorstw. [online] Available at: http://www.e-mentor.edu.pl [Accessed 16 Dec. 2017]. 